\title{
The Relationship between Self-Esteem, Satisfaction with Life and Coach-Athlete Relationship
}

\author{
Eylem Gencer (Corresponding author) \\ Department of Coaching Education, School of Physical Education and Sports \\ Kırşehir Ahi Evran University, 40100, Kırşehir, Turkey \\ Tel: 90-386-280-4773Ｅ-mail: egencer@ahievran.edu.tr
}

Received: November 30, 2020 Accepted: December 31, 2020

Published: January 4, 2021

doi:10.5296/jei.v6i2.18028 URL: https://doi.org/10.5296/jei.v6i2.18028

\begin{abstract}
The purpose of the study was to examine the relationships between the self-esteem, satisfaction with life and coach-athlete relationship, and to examine these structures according to gender, international/national status, educational status, and sport experience in an elite sport context. 206 elite judoists participated in the study. Data collected by adapted and validated forms of Rosenberg Self-Esteem Scale (RSES), Satisfaction with Life Scale (SWLS), and Coach-Athlete Relationship Questionnaire (CART-Q). Positive significant relationships were found between the constructs of RSES, SWLS, and CART-Q. Besides, female judoists' self-esteem scores were higher than their male counterparts. National judoists were closer to their coaches than international judoists in terms of coach-athlete relationship, and high-school judoists were closer and more committed towards their coaches than university judoists regarding educational status. In conclusion, positive relationships established between athletes and coaches may promote self-esteem and satisfaction with life of the athletes, and high self-esteem and satisfaction with life may enhance coach-athlete relationships.
\end{abstract}

Keywords: Coaching behavior, Self-esteem, Satisfaction with life, Coach-athlete relationship, Judoist

\section{Introduction}

The self-consciousness, which contains individual's thoughts, perceptions, and opinions about himself/herself (Rogers, 1961), affects the mental and physical health, and the relationship with others (Gander, Gardiner, \& Bass, 1981). Rosenberg (1965) describes the self-esteem as feeling the individual himself/herself sufficient and worthy. High self-esteem is one of the most 
important indicators of psychological health (Crocker \& Park, 2004), and refers to general well-being (Dubois \& Flay, 2004). Self-esteem is not a static structure, on the contrary, it is a dynamic structure (Baldwin \& Hoffmann, 2002). Although the first years of life are important for the development of self-esteem, it is not completely formed during this period and then remains the same for life (Kaplan, 1995). In other words, the interaction of the person with others (teachers, trainers, parents, friends) who he/she perceives as important, affects the self-esteem (Harter, 1993; Whitehead \& Corbin, 1997; Smoll, Smith, Barnett, \& Everett, 1993).

Self-perception is an indicator of mental health and psychological functions and it has a role in happiness, success, and establishing effective relationships with people (Folkins \& Sime, 1981; Hughes, 1984). Similarly, physical activities influence development of mental health and psychological functions as well (Aşç1, 2004). These common impacts have led to the association of self-perception with physical education and sports. Participation in physical activity is indicated to enhance the physical ability and physical fitness of the individual and thus positively affects the self-perception (Sonstroem, 1997). In the literature, there are many studies reporting that participation in exercise and sports activities affected self-esteem and self-perceptions of individuals positively (Slutzky \& Simpkins, 2009; Richman \& Shaffer, 2000; Bowker, 2006; Shaffer \& Wittes, 2006; Coatsworth \& Conroy, 2006; Percy, Dzuiban, \& Martin, 1981; Hawkins \& Gruber, 1982; Salokun, 1994; Plummer \& Koh, 1987; Trujillo, 1983; Palmer, 1995). The self-esteem, which has influence on our behaviors and motives (Fox, 1997), is not only a structure that affects our relationship with the individuals around us (Gander, Gardiner, \& Bass, 1981), but also a structure that is influenced by our relationship with the individuals around us (Harter, 1993; Whitehead \& Corbin, 1997; Smoll et al., 1993). In the sports environment, the people with whom the athletes constantly interact and value the most are their coaches. In this respect, coaches can affect their athletes' self-esteem through their approach, similarly, the self-esteem of the athletes can determine the direction of their relationships with their coaches.

The coach-athlete relationship is defined as interpersonal relationship where the emotions, thoughts, and behaviors of the coach and the athlete are causally and mutually interconnected (Jowett \& Ntoumanis, 2004; Adie \& Jowett, 2010; Isoard-Gautheur, Touilloud, Gustafsson, \& Guillet-Descas, 2016). The coach-athlete relationship has been examined in terms of well-being (Blanchard, Amiot, Perreault, Vallerant, \& Provencher, 2009; Davis \& Jowett, 2014; Jowett \& Cramer, 2009) in the literature. The studies indicated that perception of cohesiveness predicted athletes' subjective well-being (Blanchard et al., 2009). Athletes' attachment styles were associated with coach-athlete relationship quality, and in turn, relationship quality was linked athletes' well-being (Davis \& Jowett, 2014). Athletes' perceptions of satisfaction of basic psychological needs generally mediated the association between their attachment styles and well-being (Felton \& Jowett, 2013), Higher levels of perceptions of physical self were predicted by the significance athletes assigned to the depth of the relationship with the coach (Jowett \& Cramer, 2009).

Moreover, satisfaction with life, which is the general judgment and evaluations of the individual about his/her life (Diener et al., 1985), represents the cognitive aspect of subjective well-being from concepts related to human happiness (Diener, 1984). Research indicated that 
there is a positive relationship between satisfaction with life and self-esteem (Yetim, 2003; Abe, 2004; Myers \& Diener, 1995; N. Çivitçi \& A. Çivitçi, 2009; Karademir et al., 2013).

As seen in the previous studies, all three concepts are intertwined with each other and have common aspects. In this respect, it is expected that there will be a mutual interaction between the self-esteem, satisfaction with life and coach-athlete relationship. In this context, it was aimed to examine whether there is any association between self-esteem, satisfaction with life and coach-athlete relationship of elite judoists, and to examine these structures according to gender, international/national status, educational status, and sport experience.

\section{Method}

\subsection{Participants}

206 competitive judoists $(\mathrm{n}=206$; 92 women, 114 men) participated in the study. The judoists were between 17 and 33 years of age $(M=20.43, S D=2.48)$ with an average of 8.25 years of sport experience $(\mathrm{SD}=3.49)$. Among these participants, 106 were international-level athletes and 100 were national-level athletes.

\subsection{Instruments}

\subsubsection{Rosenberg Self-Esteem Scale (RSES)}

The RSES that was developed by Rosenberg (1965) and adapted to Turkish by Çuhadaroğlu (1986) is a 10-item scale that assesses an individual's perception relative to how they regard themselves. The items are rated on a 4-point scale ranging from 1 (strongly disagree) to 4 (strongly agree). The validity coefficient of the Turkish version of the RSES was 0.71 , and test-retest coefficient was 0.75 (Çuhadaroğlu, 1986). Sample items include "On the whole I am satisfied with myself", and "I feel I do not have much to be proud of". In the current study Cronbach's alpha was 0.79 .

\subsubsection{Satisfaction with Life Scale (SWLS)}

The SWLS that was developed by Diener, Emmons, Larsen, and Griffin (1985) measures a person's subjective evaluation of his or her life. The SWLS consists of five items. The items are rated on a 7-point Likert scale ranging from 1 (strongly disagree) to 7 (strongly agree). The SWLS was adapted to Turkish by Köker (1991). Test-retest coefficient for the SWLS-Turkish version was 0.85 and item-total correlations ranged between 0.71 and 0.80 (Köker, 1991). The scale includes items such as, "I am satisfied with my life" and "In most ways my life is close to my ideal". Cronbach's alpha for the current study was 0.79 .

\subsubsection{The Coach-Athlete Relationship Questionnaire (CART-Q)}

The CART-Q was developed by Jowett and Ntoumanis (2004). Turkish version of the questionnaire was adapted by Altıntaş, Çetinkalp, and Aşçı (2012). The questionnaire is used to assess the athletes' perceptions of the quality of the relationship with their coach. Internal consistency coefficients ranged from 0.82 to 0.90 for athletes in Turkish version. The CART-Q measures athletes' perceptions of closeness (e.g., "I trust my coach"), commitment (e.g., "I feel close to my coach"), and complementarity (e.g., "When I am coached by my 


\section{Macrothink}

coach, I feel responsive to his/her efforts"). The items ranged from 1 (not-et-all) to 7 (extremely). Cronbach's alphas for the current study were 0.90 for the closeness items, 0.91 for the commitment items, and 0.72 for the complementarity items.

\subsection{Procedure}

The judoists engaged in different sports clubs were contacted, the aim and content of the research were explained. The athletes who volunteered to participate in the study answered the related measurement tools under the supervision of the researcher.

\subsection{Statistical Analysis}

SPSS (Version 20.0) was performed in the analysis of data. Bivariate correlation was performed to determine the correlations between the constructs of RSES, SWLS, and CART-Q. In the comparisons of the variables regarding RSES, SWLS, and CART-Q, independent-samples t-test was used.

\section{Results}

Table 1. Means and standard deviations of RSES, SWLS and CART-Q

\begin{tabular}{|l|l|l|l|}
\hline & $\mathrm{n}$ & $\mathrm{M}$ & $\mathrm{SD}$ \\
\hline Self-Esteem & 206 & 2.99 & 0.56 \\
\hline Satisfaction with Life & 206 & 4.97 & 1.31 \\
\hline Closeness & 206 & 6.03 & 1.39 \\
\hline Commitment & 206 & 5.82 & 1.55 \\
\hline Complementarity & 206 & 5.62 & 1.35 \\
\hline
\end{tabular}

Table 1 shows the average scores of judoists obtained from the scales used in the research. The self-esteem levels of the participants were found to be $2.99(\mathrm{SD}=0.56)$. Satisfaction with life levels were found as 4.97 ( $\mathrm{SD}=1.31$ ). Besides, with respect to the level of relationship with their coaches, "closeness" average score was found to be $6.03(\mathrm{SD}=1.39)$, "commitment" average score was found to be 5.82 ( $\mathrm{SD}=1.55)$, and "complementarity" average score was found to be $5.62(\mathrm{SD}=1.35)$. 
Table 2. Correlations between RSES, SWLS and CART-Q

\begin{tabular}{|l|l|l|l|l|l|l|}
\hline & & Self-Esteem & $\begin{array}{l}\text { Satisfaction } \\
\text { with Life }\end{array}$ & Closeness & Commitment & Complementarity \\
\hline \multirow{2}{*}{ Self-Esteem } & $\mathrm{r}$ & 1 & 0.23 & 0.39 & 0.32 & 0.30 \\
\cline { 2 - 7 } & $\mathrm{p}$ & & $\mathbf{0 . 0 0 * *}$ & $\mathbf{0 . 0 0 * *}$ & $\mathbf{0 . 0 0 * *}$ & $\mathbf{0 . 0 0}^{* * *}$ \\
\hline \multirow{2}{*}{ Satisfaction with Life } & $\mathrm{r}$ & 0.23 & 1 & 0.23 & 0.26 & 0.34 \\
\cline { 2 - 7 } & $\mathrm{p}$ & $\mathbf{0 . 0 0 * *}$ & & $\mathbf{0 . 0 0}^{* *}$ & $\mathbf{0 . 0 0}^{* *}$ & $\mathbf{0 . 0 0}^{* *}$ \\
\hline
\end{tabular}

Note. $* * \mathrm{p}<0.01$.

In Table 2, the relationships between self-esteem, satisfaction with life and coach-athlete relationship were examined. As seen in Table 2, a positive, significant relationship was found between the self-esteem and satisfaction with life of the athletes $(r=0.23, p<0.01)$. In addition, there was a positive, significant relationship between the self-esteem and closeness to the coach $(\mathrm{r}=0.39, \mathrm{p}<0.01)$, commitment to the coach $(\mathrm{r}=0.32, \mathrm{p}<0.01)$, complementarity with the coach $(\mathrm{r}=0.30, \mathrm{p}<0.01)$. Furthermore, there was a positive, significant relationship between the satisfaction with life and closeness to the coach $(r=0.23$, $\mathrm{p}<0.01)$, commitment to the coach $(\mathrm{r}=0.26, \mathrm{p}<0.01)$, complementarity with the coach $(\mathrm{r}=$ $0.34, \mathrm{p}<0.01)$.

Table 3. Comparison of RSES, SWLS and CART-Q according to gender

\begin{tabular}{|c|c|c|c|c|c|c|c|}
\hline & Gender & $\mathrm{n}$ & M & SD & $\mathrm{df}$ & $\mathrm{t}$ & $\mathrm{p}$ \\
\hline \multirow{2}{*}{ Self-Esteem } & Female & 92 & 3.09 & 0.56 & \multirow{2}{*}{204} & \multirow{2}{*}{2.05} & \multirow{2}{*}{$0.04 *$} \\
\hline & Male & 114 & 2.92 & 0.57 & & & \\
\hline \multirow{2}{*}{ Satisfaction with Life } & Female & 92 & 4.97 & 1.24 & \multirow{2}{*}{204} & \multirow{2}{*}{-0.06} & \multirow{2}{*}{0.95} \\
\hline & Male & 114 & 4.98 & 1.37 & & & \\
\hline \multirow{2}{*}{ Closeness } & Female & 92 & 6.07 & 1.47 & \multirow{2}{*}{204} & \multirow{2}{*}{0.36} & \multirow{2}{*}{0.72} \\
\hline & Male & 114 & 6.00 & 1.34 & & & \\
\hline \multirow{2}{*}{ Commitment } & Female & 92 & 5.80 & 1.65 & \multirow{2}{*}{204} & \multirow{2}{*}{-0.21} & \multirow{2}{*}{0.83} \\
\hline & Male & 114 & 5.84 & 1.47 & & & \\
\hline \multirow{2}{*}{ Complementarity } & Female & 92 & 5.64 & 1.27 & \multirow{2}{*}{204} & \multirow{2}{*}{0.16} & \multirow{2}{*}{0.87} \\
\hline & Male & 114 & 5.61 & 1.42 & & & \\
\hline
\end{tabular}

Note. $* \mathrm{p}<0.05$. 


\section{Macrothink}

In Table 3, the self-esteem, satisfaction with life and coach-athlete relationship of judoists were examined regarding gender. As can be seen in Table 3, female judoists' self-esteem levels were found to be significantly higher than their male counterparts $(t=2.05, p<0.05)$. However, satisfaction with life $(t=-0.06, p>0.05)$, closeness to the coach $(t=0.36, p>$ $0.05)$, commitment to the coach $(\mathrm{t}=-0.21, \mathrm{p}>0.05)$, and complementarity with coach $(\mathrm{t}=$ $0.16, \mathrm{p}>0.05)$ did not differ according to the gender.

Table 4. Comparison of RSES, SWLS and CART-Q in terms of international/national status

\begin{tabular}{|c|c|c|c|c|c|c|c|}
\hline & International/National Status & $\mathrm{n}$ & M & SD & df & $\mathrm{t}$ & $\mathrm{p}$ \\
\hline \multirow{2}{*}{ Self-Esteem } & International & 106 & 3.00 & 0.58 & \multirow{2}{*}{204} & \multirow{2}{*}{0.17} & \multirow{2}{*}{0.86} \\
\hline & National & 100 & 2.99 & 0.55 & & & \\
\hline \multirow{2}{*}{ Satisfaction with Life } & International & 106 & 5.08 & 1.35 & \multirow{2}{*}{204} & \multirow{2}{*}{1.30} & \multirow{2}{*}{0.19} \\
\hline & National & 100 & 4.84 & 1.26 & & & \\
\hline \multirow{2}{*}{ Closeness } & International & 106 & 5.84 & 1.40 & \multirow{2}{*}{204} & \multirow{2}{*}{-1.99} & \multirow{2}{*}{$0.04 *$} \\
\hline & National & 100 & 6.23 & 1.36 & & & \\
\hline \multirow{2}{*}{ Commitment } & International & 106 & 5.69 & 1.49 & \multirow{2}{*}{204} & \multirow{2}{*}{-1.18} & \multirow{2}{*}{0.23} \\
\hline & National & 100 & 5.95 & 1.60 & & & \\
\hline \multirow{2}{*}{ Complementarity } & International & 106 & 5.51 & 1.38 & \multirow{2}{*}{204} & \multirow{2}{*}{-1.09} & \multirow{2}{*}{0.27} \\
\hline & National & 100 & 5.72 & 1.32 & & & \\
\hline
\end{tabular}

Note. ${ }^{*} \mathrm{p}<0.05$.

In Table 4, the self-esteem, satisfaction with life and coach-athlete relationship of judoists were examined with regard to international/national status. Results demonstrated national judoists' closeness scores were significantly higher than international judoists' $(t=-1.99, p<$ $0.05)$. On the other hand, self-esteem $(\mathrm{t}=0.17, \mathrm{p}>0.05)$, satisfaction with life $(\mathrm{t}=1.30, \mathrm{p}>$ $0.05)$, commitment to coach $(\mathrm{t}=-1.18, \mathrm{p}>0.05)$ and complementarity with coach $(\mathrm{t}=-1.09$, $\mathrm{p}>0.05)$ did not differ according to international/national status. 
Table 5. Comparison of RSES, SWLS and CART-Q according to educational status

\begin{tabular}{|c|c|c|c|c|c|c|c|}
\hline & Educational Status & $\mathrm{n}$ & M & $\mathrm{SD}$ & $\mathrm{df}$ & $\mathrm{t}$ & $\mathrm{p}$ \\
\hline \multirow{2}{*}{ Self-Esteem } & High School & 50 & 3.08 & 0.49 & \multirow{2}{*}{204} & \multirow{2}{*}{1.30} & \multirow{2}{*}{0.19} \\
\hline & University & 156 & 2.96 & 0.59 & & & \\
\hline \multirow{2}{*}{ Satisfaction with Life } & High School & 50 & 4.95 & 0.91 & \multirow{2}{*}{204} & \multirow{2}{*}{-0.11} & \multirow{2}{*}{0.90} \\
\hline & University & 156 & 4.97 & 1.41 & & & \\
\hline \multirow{2}{*}{ Closeness } & High School & 50 & 6.80 & .45 & \multirow{2}{*}{204} & \multirow{2}{*}{4.70} & \multirow{2}{*}{$0.00 * *$} \\
\hline & University & 156 & 5.78 & 1.50 & & & \\
\hline \multirow{2}{*}{ Commitment } & High School & 50 & 6.48 & 0.79 & \multirow{2}{*}{204} & \multirow{2}{*}{3.54} & \multirow{2}{*}{$0.00 * *$} \\
\hline & University & 156 & 5.61 & 1.67 & & & \\
\hline \multirow{2}{*}{ Complementarity } & High School & 50 & 5.88 & 0.78 & \multirow{2}{*}{204} & \multirow{2}{*}{1.57} & \multirow{2}{*}{0.11} \\
\hline & University & 156 & 5.53 & 1.48 & & & \\
\hline
\end{tabular}

Note. ${ }^{* *} \mathrm{p}<0.01$

In Table 5, the self-esteem, satisfaction with life and coach-athlete relationship of judoists were examined with regard to educational status. Results put forward high school judoists' closeness $(\mathrm{t}=4.70, \mathrm{p}<0.01)$ and commitment $(\mathrm{t}=3.54, \mathrm{p}<0.01)$ scores were significantly higher than their university counterparts'. However, self-esteem $(\mathrm{t}=1.30, \mathrm{p}>0.05)$, satisfaction with life $(\mathrm{t}=-0.11, \mathrm{p}>0.05)$ and complementarity with the coach $(\mathrm{t}=1.57, \mathrm{p}>$ 0.05 ) did not differ according to educational status.

Table 6. Correlations between sport experience and RSES, SWLS and CART-Q

\begin{tabular}{|l|l|l|l|l|l|l|}
\hline & & Self-Esteem & $\begin{array}{l}\text { Satisfaction } \\
\text { with Life }\end{array}$ & Closeness & Commitment & Complementarity \\
\hline \multirow{2}{*}{ Sport Experience } & $\mathrm{r}$ & -0.07 & 0.17 & -0.05 & -0.04 & -0.07 \\
\cline { 2 - 7 } & $\mathrm{p}$ & 0.33 & $\mathbf{0 . 0 1 *}$ & 0.51 & 0.54 & 0.32 \\
\hline
\end{tabular}

Note. ${ }^{*} \mathrm{p}<0.05$.

Table 6 presents the relationships between the sport experience and self-esteem, coach athlete relationship. There was positive, significant relationship between the sport experience and satisfaction with life $(\mathrm{r}=0.17, \mathrm{p}<0.05)$. There was no significant relationship between the sport experience and self-esteem $(r=-0.07, p>-0.05)$, closeness to the coach $(r=-0.05, p>$ 
$0.05)$, commitment to the coach $(r=-0.04, p>0.05)$, complementarity with the coach $(r=$ $-0.07, \mathrm{p}>0.05)$.

\section{Discussion and Conclusion}

In the study, the relationships between the self-esteem, satisfaction with life, and coach-athlete relationship were examined, and these constructs were compared with regard to gender, international/national status, educational status, and sport experience. Positive and significant relationships were found between the self-esteem, satisfaction with life and coach-athlete relationship. In addition, female judoists' self-esteem scores were significantly higher than their male counterparts. National judoists' closeness and commitment scores were found to be higher than international judoists'. High school judoists were closer to their coaches than university judoists. Sport experience of the judoists were correlated with satisfaction with life.

High self-esteem is one of the important indicators of psychological health (Crocker \& Park, 2004) and refers to the general well-being (Dubois \& Flay, 2004). As it is a dynamic structure (Baldwin \& Hoffmann, 2002), it does not only affect our relationship with the people around us (Gander, Gardiner \& Bass, 1981), it is also influenced by our interactions and relationships with individuals we consider important (Harter, 1993; Whitehead \& Corbin, 1997; Smoll et al., 1993). Besides self-esteem affects the coach-athlete relationship, the coach-athlete relationship also affects self-esteem (Lyle, 1999). The most important individuals perceived by athletes in sports environments are their coaches. When evaluated from this point of view, the positive interaction and relations of coaches with their athletes can increase the self-esteem of the athletes and this heightened self-esteem can strengthen athletes' relationships with their coaches as well. Regardless of the point of view, self-esteem and coach-athlete relationship are in a mutual interaction and they support each other. It is obvious that more detailed studies, especially qualitative studies are needed to clarify the interactions between these structures.

The other result in research indicated satisfaction with life was related to closeness and commitment to the coach, and complementarity with the coach. Coach-athlete relationship is one of the main factors that can affect the satisfaction of the athletes (Lyle, 1999). In addition, there are studies in the literature showing that the coach-athlete relationship and satisfaction with life are related (Jowett \& Ntoumanis, 2004; Price \& Weiss, 2000; Sagar, Lavallee, \& Spray, 2009; Jowett \& Cockerill, 2003; Poczwardowski, Barott, \& Henschen, 2002; Wylleman, 2000). In the light of these findings, a positive relationship between the coaches and their athletes can increase the life satisfaction of the athletes and thus the closeness, commitment, and complementarity of the athletes to their coaches can be reinforced. As in self-esteem, there is a mutual interaction between satisfaction with life and coach-athlete relationship. So, the subject needs to be examined in depth in order to understand whether satisfaction with life leads desired coach-athlete relationship or positive coach-athlete relationship makes the athletes be happy in their lives.

There was also a positive relationship between self-esteem and satisfaction with life. In parallel with the result, there are studies showing the interaction between self-esteem and 
satisfaction with life (Yetim, 2003; Abe, 2004; Myers \& Diener, 1995; N. Çivitçi \& A. Çivitçi, 2009; Karademir et al., 2013). Athletes who perceive themselves as sufficient and worthy can be expected to have a positive perception of their lives. Similarly, athletes who feel happy themselves in their lives can be expected to have positive self-perceptions.

In the research, self-esteem, satisfaction with life and coach-athlete relationship were also examined in terms of gender, international/national status, educational status, and sport experience. Female judoists' self-esteem levels were found to be higher than male judoists'. Besides, in terms of the coach-athlete relationship, national judoists were found to have higher average of closeness, commitment, and complementarity to their coaches than international judoists, but the significant difference was observed in the closeness dimension. In terms of educational status, the high school judoists were closer and more committed to their coaches than the university judoists. Sport experience of judoists was related to satisfaction with life. Female athletes' high self-esteem levels may be derived from personality traits, as well as positive coach-athlete relationship. The difference between international and national judoists in terms of coach-athlete relationships, may be attributed to "autonomy". International athletes may be more autonomous than national athletes. However, many reasons arising from the coach, athlete and environment can cause this result. Similarly, the closeness differences with regard to educational status, may be resulted from insight distinction gained by education. But it may not be attributed only to education. Coaches, athletes, and settings may all have caused this result. The association between the satisfaction with life and sport experience may also be resulted from the performance accomplishments during their sport career. Even so, to ensure the reliability of the results qualitative research are needed.

In conclusion, there are positive correlations between self-esteem, satisfaction with life and coach-athlete relationship. In addition, self-esteem differed with regard to gender, closeness to coach differed in terms of international/national status, closeness and commitment to coach differed with regard to educational status, and sport experience was correlated with satisfaction with life. The positive correlations between self-esteem, satisfaction with life and coach-athlete relationship suggest some important implications to the researchers and practitioners in the field. High self-esteem and satisfaction with life of the athletes' link to a better coach-athlete relationship. Similarly, positive relationships between coaches and athletes link to high self-esteem and satisfaction with life of the athletes. Coaches are the crucial actors in creating this climate and enhancing athletes' self-esteem, satisfaction with life and relationships with them through positive interactions. By establishing positive relationships with their athletes, coaches can both increase athletes' self-esteem and life satisfaction and reinforce their closeness, commitment, and complementarity with them. So, they can hit two birds with one stone, so to speak.

Finally, some limitations of the research should be mentioned. The results of the study provide generalizations about the elite judoists. Conducting similar studies in different branches may contribute to the generalizability of the findings. In addition, patterns between self-esteem, satisfaction with life, and coach-athlete relationship can be explored in depth with qualitative research and a more detailed and holistic approach can be provided. 


\section{References}

Abe, J. A. A. (2004). Self-esteem, perception of relationships, and emotional distress: A cross-cultural study. Personal Relationships, 11(2), 231-247. https://doi.org/10.1111/ j.1475-6811.2004.00080.x

Adie, J. W., \& Jowett, S. (2010). Meta-perceptions of the coach-athlete relationship, achievement goals, and intrinsic motivation among sport participants. Journal of Applied Social Psychology, 40(11), 2750-2773. https://doi.org/10.1111/j.1559-1816.2010.00679.x

Altıntaş, A., Çetinkalp, Z. K., \& Aşçı, F. H. (2012). Evaluating the coach-athlete relationship: Validity and reliability study. Hacettepe Journal of Sport Sciences, 23(3), 119-128.

Aşç1, F. H. (2004). Self-perception and exercise. Hacettepe Journal of Sport Sciences, 15(4), 233-266.

Baldwin, S. A., \& Hoffmann, J. P. (2002). The dynamics of self-esteem: A growth-curve analysis. Journal of Youth and Adolescence, 31(2), 101-113. https://doi.org/10.1023/ A:1014065825598

Blanchard, C. M., Amiot, C. E., Perreault, S., Vallerand, R. J., \& Provencher, P. (2009). Cohesiveness, coach's interpersonal style and psychological needs: Their effects on self-determination and athletes' subjective well-being. Psychology of Sport and Exercise, 10(5), 545-551. https://doi.org/10.1016/j.psychsport.2009.02.005

Bowker, A. (2006). The relationship between sports participation and self-esteem during early adolescence. Canadian Journal of Behavioural Science, 38(3), 214-229. https://doi.org/ $10.1037 /$ cjbs2006009

Coatsworth, J. D., \& Conroy, D. E. (2006). Enhancing the self-esteem of youth swimmers through coach training: Gender and age effects. Psychology of Sport and Exercise, 7(2), 173-192. https://doi.org/10.1016/j.psychsport.2005.08.005

Crocker, J., \& Park, L. E. (2004). The costly pursuit of self-esteem. Psychological Bulletin, 130(3), 392-414. https://doi.org/10.1037/0033-2909.130.3.392

Çivitci, N., \& Çivitci, A. (2009). Self-esteem as mediator and moderator of the relationship between loneliness and life satisfaction in adolescents. Personality and Individual Differences, 47(8), 954-958. https://doi.org/10.1016/j.paid.2009.07.022

Çuhadaroglu, F. (1986). Self-esteem in adolescents. Unpublished doctoral dissertation, Hacettepe University, Turkey.

Davis, L., \& Jowett, S., (2014). Coach-athlete attachment and the quality of the coach-athlete relationship: Implications for athlete's well-being. Journal of Sports Sciences, 32(15), 1454-1464. https://doi.org/10.1080/02640414.2014.898183

Diener, E. (1984). Subjective well-being. Psychological Bulletin, 95(3), 542-575. https://doi.org/10.1037/0033-2909.95.3.542 
Diener, E. D., Emmons, R. A., Larsen, R. J., \& Griffin, S. (1985). The satisfaction with life scale. Journal of Personality Assessment, 49(1), 71-75. https://doi.org/10.1207/s15327752 jpa4901_13

DuBois, D. L., \& Flay, B. R. (2004). The healthy pursuit of self-esteem: Comment on and alternative to the Crocker and Park (2004) Formulation. Psychological Bulletin, 130(3), 415-420. https://doi.org/10.1037/0033-2909.130.3.415

Felton, L., \& Jowett, S. (2013). The mediating role of social environmental factors in the associations between attachment styles and basic needs satisfaction. Journal of Sports Sciences, 31(6), 618-628. https://doi.org/10.1080/02640414.2012.744078

Folkins, C. H., \& Sime, W. E. (1981). Physical fitness training and mental health. American Psychologist, 36(4), 373-389. https://doi.org/10.1037/0003-066X.36.4.373

Fox, K. R. (1997). Processes in the development of self-esteem and the physical self. In K. R. Fox (Ed.), The physical self: From motivation to well-being (pp. 111-139). Champaign, IL: Human Kinetics.

Gander, M. J., Gardiner, H. W., \& Bass, G. M. (1981). Child and adolescent development. Little, Brown.

Harter, S. (1993). Causes and consequences of low self-esteem in children and adolescents. In R. F. Baumeister (Ed.), Self-Esteem (pp. 87-116). Springer, Boston, MA. https://doi.org/ 10.1007/978-1-4684-8956-9_5

Hawkins, D. B., \& Gruber, J. J. (1982). Little league baseball and players' self-esteem. Perceptual and Motor Skills, 55(3), 1335-1340. https://doi.org/10.2466/pms.1982.55.3f.1335

Hughes, H. M. (1984). Measures of self-concept and self-esteem for children ages 3-12 years: A review and recommendations. Clinical Psychology Review, 4(6), 657-692. https://doi.org/ $10.1016 / 0272-7358(84) 90011-4$

Isoard-Gautheur, S., Trouilloud, D., Gustafsson, H., \& Guillet-Descas, E. (2016). Associations between the perceived quality of the coach-athlete relationship and athlete burnout: An examination of the mediating role of achievement goals. Psychology of Sport and Exercise, 22, 210-217. https://doi.org/10.1016/j.psychsport.2015.08.003

Jowett, S., \& Cockerill, I. M. (2003). Olympic medallists' perspective of the athlete-coach relationship. Psychology of Sport and Exercise, 4(4), 313-331. https://doi.org/10.1016/ S1469-0292(02)00011-0

Jowett, S., \& Cramer, D. (2009). The role of romantic relationships on athletes' performance and well-being. Journal of Clinical Sport Psychology, 3(1), 58-72. https://doi.org/10.1123/ jcsp.3.1.58

Jowett, S., \& Ntoumanis, N. (2004). The coach-athlete relationship questionnaire (CART-Q): Development and initial validation. Scandinavian Journal of Medicine \& Science in Sports, 14(4), 245-257. https://doi.org/10.1111/j.1600-0838.2003.00338.x 
Kaplan, L. S. (1995). Self-esteem is not our national wonder drug. The School Counselor, 42(5), 341-345.

Karademir, T., Türkçapar, Ü., Ulucan, H., \& Bahadır, Z. (2013). Evaluation of the correlation between self-esteem and satisfaction with life and body image perception in weightlifters. Kırşehir Eğitim Fakültesi Dergisi, 14(3), 285-294.

Köker, S. (1991). Comparison of the level of life satisfaction of normal adolescents and adolescents with problems (Unpublished master's dissertation, Ankara University, Turkey).

Lyle, J. (1999). Coaching philosophy and coaching behaviour. In N. Cross \& J. Lyle (Eds.), The coaching process: Principles and practice for sport (pp. 25-46). Oxford: Butterworth-Heineman.

Myers, D. G., \& Diener, E. (1995). Who is happy? Psychological Science, 6(1), 10-19. https://doi.org/10.1111/j.1467-9280.1995.tb00298.x

Palmer, L. K. (1995). Effects of a walking program on attributional style, depression, and self-esteem in women. Perceptual and Motor Skills, 81(3), 891-898. https://doi.org/ 10.2466/pms.1995.81.3.891

Percy, L. E., Dziuban, C. D., \& Martin, J. B. (1981). Analysis of effects of distance running on self-concepts of elementary students. Perceptual and Motor Skills, 52(1), 42. https://doi.org/10.2466/pms.1981.52.1.42

Plummer, O. K., \& Koh, Y. O. (1987). Effect of "aerobics" on self-concepts of college women. Perceptual and Motor Skills, 65(1), 271-275. https://doi.org/10.2466/pms.1987. 65.1 .271

Poczwardowski, A., Barott, J. E., \& Henschen, K. P. (2002). The athlete and coach: Their relationship and its meaning. Results of an interpretive study. International Journal of Sport Psychology, 33(1), 116-140.

Price, M. S., \& Weiss, M. R. (2000). Relationships among coach burnout, coach behaviors, and athletes' psychological responses. The Sport Psychologist, 14(4), 391-409. https://doi.org/10.1123/tsp.14.4.391

Richman, E. L., \& Shaffer, D. R. (2000). "If you let me play sports": How might sport participation influence the self-esteem of adolescent females? Psychology of Women Quarterly, 24(2), 189-199. https://doi.org/10.1111/j.1471-6402.2000.tb00200.x

Rogers, C. R. (1961). On becoming a Person: A therapist's view of psychotherapy. Boston: Houghton Mifflin Company.

Rosenberg, M. (1965). Society and the adolescent self-image. Princeton, NJ: Princeton University Press. https://doi.org/10.1515/9781400876136

Sagar, S. S., Lavallee, D., \& Spray, C. M. (2009). Coping with the effects of fear of failure: A preliminary investigation of young elite athletes. Journal of Clinical Sport Psychology, 3(1), 73-98. https://doi.org/10.1123/jcsp.3.1.73 


\section{Macrothink}

Salokun, S. O. (1994). Positive change in self-concept as a function of improved performance in sports. Perceptual and Motor Skills, 78(3), 752-754. https://doi.org/10.1177/0031512594 07800314

Shaffer, D. R., \& Wittes, E. (2006). Women's precollege sports participation, enjoyment of sports, and self-esteem. Sex Roles, 55(3-4), 225-232. https://doi.org/10.1007/s11199006-9074-3

Slutzky, C. B., \& Simpkins, S. D. (2009). The link between children's sport participation and self-esteem: Exploring the mediating role of sport self-concept. Psychology of Sport and Exercise, 10(3), 381-389. https://doi.org/10.1016/j.psychsport.2008.09.006

Smoll, F. L., Smith, R. E., Barnett, N. P., \& Everett, J. J. (1993). Enhancement of children's self-esteem through social support training for youth sport coaches. Journal of Applied Psychology, 78(4), 602-610. https://doi.org/10.1037/0021-9010.78.4.602

Sonstroem, R. J. (1997). The physical self-system: A mediator of exercise and self-esteem. In K. R. Fox (Ed.), The physical self: From motivation to well-being (pp. 3-26). Champaign, IL, US: Human Kinetics.

Trujillo, C. M. (1983). The effect of weight training and running exercise intervention programs on the self-esteem of college women. International Journal of Sport Psychology, 14(3), 162-173.

Whitehead, J. R., \& Corbin, C. B. (1997). Self-esteem in children and youth: The role of sport and physical education. In K. R. Fox (Ed.), The physical self: From motivation to well-being (pp. 175-203). Champaign, IL, US: Human Kinetics.

Wylleman, P. (2000). Interpersonal relationships in sport: Uncharted territory in sport psychology research. International Journal of Sport Psychology, 31(4), 555-572.

Yetim, U. (2003). The impacts of individualism/collectivism, self-esteem, and feeling of mastery on life satisfaction among the Turkish university students and academicians. Social Indicators Research, 61(3), 297-317. https://doi.org/10.1023/A:1021911504113

\section{Copyright Disclaimer}

Copyright for this article is retained by the author(s), with first publication rights granted to the journal.

This is an open-access article distributed under the terms and conditions of the Creative Commons Attribution license (http://creativecommons.org/licenses/by/3.0/). 